\title{
Bone Scintigraphy Scanning Safety and Necessity for Silent and Multifocal Osteonecrosis in Sickle Cell Disease
}

\begin{abstract}
Keywords: Bone scan; Avascular necrosis; Sickle cell anemia; MRI; SPECT

Abstract

Sickle cell disease is a congenital autosomal recessive disease. The predominant pathophysiological feature is vaso cclusion, which leads to acute and chronic complications. Multifocal and silen progressive osteonecrosis over the whole skeleton is one of the major complications of this disorder, requiring follow-up, prophylaxis, and treatment. Bone scintigraphy scanning is widely used, relatively inexpensive, well-tolerated, and has an accuracy of over $90 \%$. MRI is the gold standard imaging technique, however, it has a higher specificity than bone scintigraphy, but it may require contrast dye, which could be nephrotoxic, as sickle cell disease nephropathy is a common complication in such patients. For screening purposes and follow-up of bone integrity, a bone scan can detect silent and multifocal osteonecrosis without the need for contrast dye, which makes it a safe and necessary tool for bone complication follow-up before the osteonecrotic asymptomatic joints develop to advance stages without being noticed by the patient.
\end{abstract}

\section{Sickle Cell Disease}

Sickle cell disease (SCD) is a congenital autosomal recessive disease characterized by structural abnormality in the beta-globin chain of the hemoglobin molecule. Every year approximately 300,000 children are born with the disease [1]. SCD mutation is a single base change (GAT $\rightarrow$ GTT) in the sixth codon of exon- 1 of the beta globin gene on chromosome 11. According to this mutation, the normal glutamic acid is substituted with valine acid, resulting in the formation of hemoglobin (HbS). This amino acid substitution changes the hemoglobin $S$ to a "sickle" shape in the deoxygenated state. The ability of these sickled cells to adapt to the surroundings is impaired, especially in the microvasculature [2]. SCD is characterized by chronic hemolytic anemia with numerous clinical consequences. It is a well-recognized cause of progressive osteonecrosis of the femoral and humeral heads, which causes potential disability $[3,4]$. The predominant pathophysiological feature of SCD is vaso cclusion that leads to acute and chronic complications including severe pain episodes with dramatic hemolysis, avascular necrosis, acute chest syndrome, and stroke. The complications progress to involve multiple organs, including the central nervous system, cardiovascular system, lung, liver, bone, skin, and kidneys [5]. Nephropathy is a prominent complication in SCD [6-8]. The use of contrast dye could affect renal integrity and may lead to renal failure [9].
Journal of

Hematology \& Thrombosis

\section{Hassan Al-Jafar ${ }^{1 *}$, Mahmoud AlFeeli ${ }^{2}$, Fayza Abdulla Alhajri ${ }^{3}$, Thamer A Abdullah ${ }^{3}$ and Eman Al-Shemmeri ${ }^{4}$}

${ }^{I}$ Department of Heamtology, Amiri Hospital, Kuwait City, Kuwait ${ }^{2}$ Department of Nuclear Medicine, Mubarak Al-Kabeer Hospital, Jabria, Kuwait

${ }^{3}$ Department of Radiology, Amiri Hospital, Kuwait City, Kuwait ${ }^{4}$ Department of Nuclear Medicine, Al-Farwania Hospital, Kuwait

\section{*Address for Correspondence:}

Hassan Al-Jafar, Amiri Hospital, Kuwait City, Kuwait, Tel: 0096599624499; E-mail: cbc9@hotmail.com

\section{Submission: 20 February, 2016}

Accepted: 03 March, 2016

Published: 09 March, 2016

Copyright: () 2015 Al-Jafar H, et al. This is an open access article distributed under the Creative Commons Attribution License, which permits unrestricted use, distribution, and reproduction in any medium, provided the original work is properly cited.

Reviewed \& Approved by: Dr. Raul H. Morales-Borges, American Red Cross in San Juan, Practices, Ashford Institute of Hematology \& Oncology, USA

\section{Bone Scintigraphy}

Bone scintigraphy (BSc) in SCD is a diagnostic functional imaging technique to evaluate the distribution of active bone formation in the body. Since it was applied more than 40 years ago, BSc has played a significant role in the detection and diagnosis of different bone lesions. Following intravenous administration, the radionuclide fixes itself to the bone proportionally with bone metabolism [10]. The procedure is performed with technetium-99mlabeled in diphosphonates (99mTc-MDP). The degree of radiotracer uptake depends on two factors: blood flow, and more importantly, the rate of new bone formation. BSc is one of the most frequently performed of all radionuclide procedures [11]. It is widely used, relatively cheap, well tolerated and has an accuracy of more than $90 \%$ [12]. It is useful in scanning osteonecrosis in SCD patients, one of the main complications of this disease. BSc shows abnormalities within a few days to 2 weeks before the radiographic changes become obvious. The preferred way to perform the test is to use a multiphase (threephase) method, which assesses the degree of hyperemia (flow phase), increased articular permeability (blood pool phase) and the presence of unpaired bone metabolism turnover (bone tissue phase) at different times $[13,14]$. BSc is an established diagnostic modality for a variety of pathologies involving the skeleton, such as osteomyelitis, bone metastases, osteonecrosis, and occult fractures or occult infection. In more recently introduced types of instrumentation, the Single Photon Emission Computed Tomography (SPECT) localizes abnormalities and changes in three dimensions of the entire skeleton [15-17]. It gives a positive criterion for osteonecrosis as a cold defect in the femoral head [18]. BSc is a non-invasive tool for detection of osteonecrosis anywhere in the whole body, even in uncommon sites due to its high sensitivity [19]. It is also useful in clinical situations where physical examination and $\mathrm{x}$-ray fail to localize the source of pain [20]. BSc can 
Citation: Al-Jafar H, AlFeeli M, Alhajri FA, Abdullah TA, Al-Shemmeri E. Bone Scintigraphy Scanning Safety and Necessity for Silent and Multifocal Osteonecrosis in Sickle Cell Disease. J Hematol Thromb 2016;2(1): 4.

ISSN: $2380-6842$

Table 1: Typical effective radiation doses [46]

\begin{tabular}{|c|c|}
\hline Exam & Effective Dose mSv \\
\hline Chest (LAT) & 0.04 \\
\hline Chest (AP) & 0.02 \\
\hline Skull (AP) & 0.03 \\
\hline Skull (Lat) & 0.01 \\
\hline Pelvis (AP & 0.7 \\
\hline Thoracic Spine (AP) & 0.4 \\
\hline Lumber (AP) & 0.7 \\
\hline Exam & Effective Dose mSv \\
\hline Mammogram (four views) & 0.7 \\
\hline Dental (lateral) & 0.02 \\
\hline Dental (panoramic) & 0.09 \\
\hline DEXA (whole body) & 0.0004 \\
\hline Hip & 0.8 \\
\hline Hand or Foot & 0.005 \\
\hline Abdomen & 1.2 \\
\hline Exam & Effective Dose mSv \\
\hline Intravenous Pyelogram (kidneys, six films) & 2.5 \\
\hline Barium Swallow (24 images, 106 sec. fluoroscopy) & 1.5 \\
\hline Barium Enema (10 images, 137 sec. fluoroscopy) & 7 \\
\hline CT Head & 2 \\
\hline CT Chest & 8 \\
\hline CT Abdomen & 10 \\
\hline CT Pelvis & 10 \\
\hline Angioplasty (heart study) & $7.5-57.0$ \\
\hline Coronary Angiogram & $4.6-15.8$ \\
\hline
\end{tabular}

reliably detect areas of infarction in the acute phase. This approach was used to show that infarcts in SCD can occur in every bone in the body [21]. A radionuclide bone scan usually shows positive results within 48 to 72 hours of onset of symptoms [22]. Nuclear imaging indicates regions of increased metabolic activity (hot spots) by an increased uptake of a radioactive tracer. It is useful in detecting bone metastatic disease, osteomyelitis, osteonecrosis, arthritis, and Paget's disease [23]. BSc can examine multiple bones and joints lesions at one time on total body imaging to determining whether multiple osteonecrosis develops in other parts in the body [24]. The high sensitivity of the bone scan for detection of skeletal lesions and the ability to image the entire skeleton were maintained in its role in oncology imaging [25]. In SCD also, the high sensitivity of a bone scan is required to detect bone involvement. In a multicenter study of symptomatic multifocal osteonecrosis, various authors suggested that a total body BSc may be the most cost-effective means of screening for multifocal involvement [26], when the multifocal lesions are not recognizable on plain radiography before localized by BSc technology [27]. The SCD osteonecrosis could be completely clinically silent [28].

\section{Bone Marrow Scintigraphy in SCD}

It is a diagnostic tool for staging several hematological bone marrow disorders. It can also be indicated to detect sepsis in bone marrow. Bone marrow imaging using radionuclides may be divided into three categories: imaging the reticuloendothelial system, imaging the erythroid precursor cells, and imaging the myeloid compartment in the bone marrow. Two other pathways for imaging the bone marrow have recently been developed in research, and applications of positron emission tomography (PET) include scans for metabolic activity and proliferative activity [29]. The combination of bone marrow scintigraphy and immediately sequential skeletal scintigraphy has been shown to accurately identify sites of osteomyelitis, location and distribution of osteonecrosis, as well as the healing patterns of bone marrow infarcts, which may be valuable in SCD treatment and management [30]. The overall accuracy of combined leukocyte and marrow imaging is approximately $90 \%$ [31].

\section{MRI versus BSc}

Magnetic resonance imaging (MRI) in SCD is the gold standard to diagnose osteonecrosis [32], but although BSc is less specific it is more sensitive than MRI [33]. Osteonecrosis in SCD can be silent and multifocal, and will therefore be missed if only MRI was done [31]. BSc is safe and requires a small irradiation dose compared to other irradiation procedures (Table 1). After injection with the radiopharmaceutical material the patient becomes slightly radioactive for a short time (Table 2). The BSc irradiation dose is $4.2 \mathrm{mSv}$, which is less than what is required for tumors, infections and heart scintigraphy. The irradiation exposure becomes hazardous after it exceeds $100 \mathrm{mSv}$ per year, which is far from BSc requirements [34-36]. One of the most important advantages of BSc is that it does not need contrast dye while MRI sometimes requires contrast dye to visualize the lesions $[37,38]$. The contrasts dye is not preferable in SCD patients as the renal function is potentially under threat of SCD nephropathy $[39,40]$. If in local radiographs only MRI is applied to detect osteonecrosis, there will be a risk of underestimating the multifocal osteonecrosis since these patients has silent, painless lesions, where the osteonecrosis does not occur at the same time, and

Table 2: Typical effective nuclear medicine doses [46].

\begin{tabular}{|c|c|c|}
\hline & & Effective \\
\hline Medicine Scan & Radiopharmaceutical & Dose mSv \\
\hline Brain (PET) & ${ }^{15} \mathrm{O}$ water & 1 \\
\hline Brain (perfusion) & ${ }^{99 m}$ Tc HMPAO & 6.9 \\
\hline Hepatobiliary (liver flow) & ${ }^{99 m}$ Tc Sulfur Colloid & 2.8 \\
\hline Bone & 99m TC MPD & 4.2 \\
\hline Lung Perfusion/Ventilation & ${ }^{99 m}$ Tc MAA \& ${ }^{133} \mathrm{Xe}$ & 2 \\
\hline Kidney (filtration rate) & 99m Tc DTPA & 3.6 \\
\hline Kidney (tubular function) & 99m Tc MAG3 & 5.2 \\
\hline Tumor/Infection & ${ }^{67} \mathrm{Ga}$ & 18.5 \\
\hline Heart (rest) & ${ }^{99 m}$ Tc sestimibi & 6.7 \\
\hline Heart (Stress) & ${ }^{99 m}$ Tc sestamibi & 5.85 \\
\hline Heart & TI chloride 201 & 11.8 \\
\hline Heart (rest) & ${ }^{99 m}$ Tc-tetrofosmin (Myoview & 5.6 \\
\hline Heart (stress) & ${ }^{99 m}$ Tctetrofosmin (Myoview) & 5.6 \\
\hline Various PET Studies & ${ }^{18}$ F FDG $14.0(1,400)$ & 14 \\
\hline
\end{tabular}


Citation: Al-Jafar H, AlFeeli M, Alhajri FA, Abdullah TA, Al-Shemmeri E. Bone Scintigraphy Scanning Safety and Necessity for Silent and Multifocal Osteonecrosis in Sickle Cell Disease. J Hematol Thromb 2016;2(1): 4.

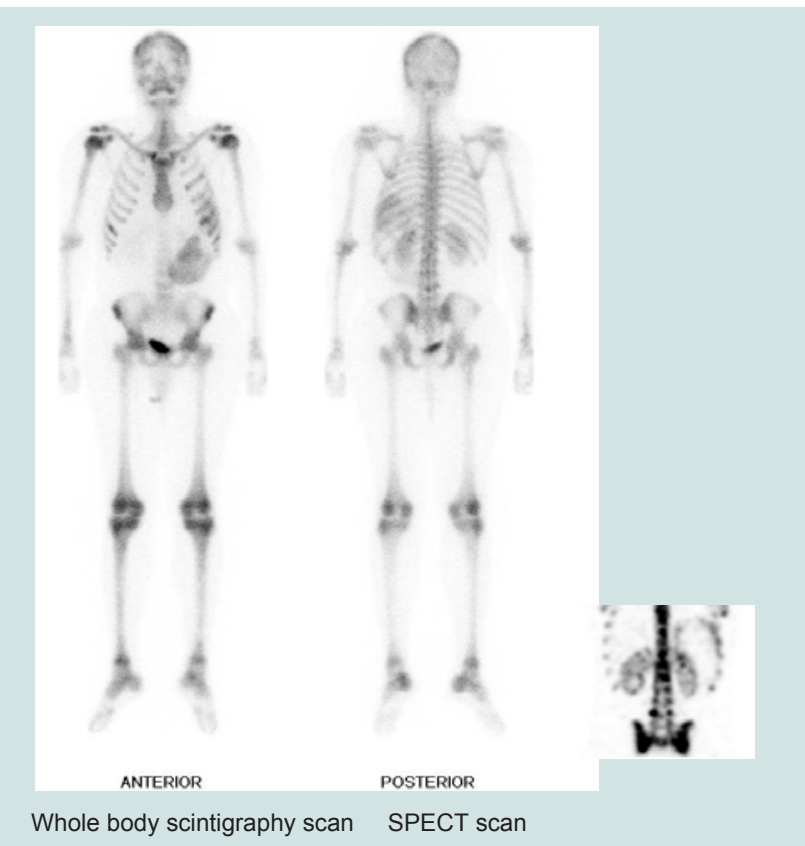

Figure 1: Whole body scintigraphy-SPECT scan for sickle cell patient with anterior right 8 th rib and anterior left 3rd \& 6-8th ribs beside L4 and L1 multifocal osteonecrosis.

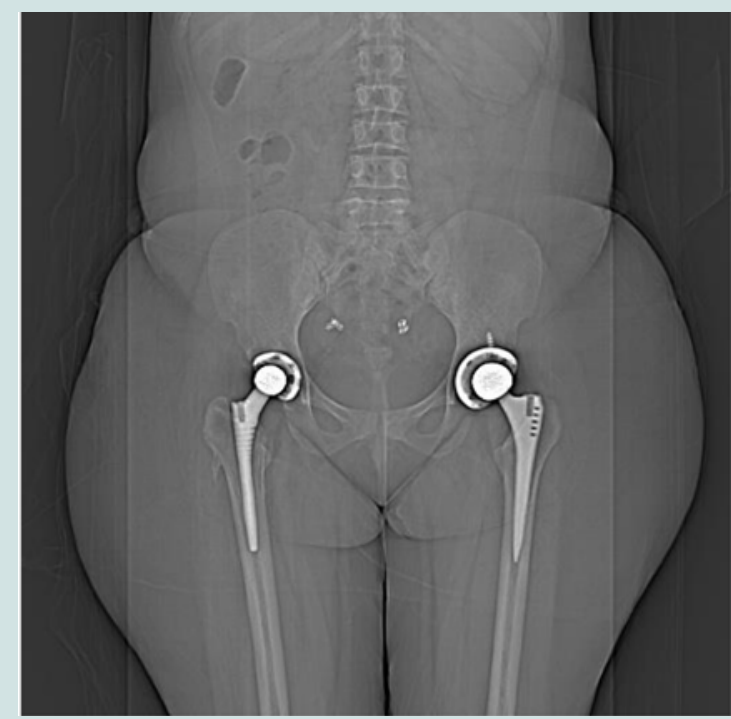

Figure 2: Sickle cell patient with multifocal osteonecrosis replaced with both side metal hip arthroplasty.

all joints do not become symptomatic at the same time (Figure 1) $[41,42]$. The silent onset of osteonecrosis in SCD, present with mild or with non-specific symptoms, could be followed by joint bilateral collapsed fractures and lead to the need for total joint replacement (Figure 2) [43]. The vast majority of osteonecrotic lesions remain silent at follow-up, although collapse can occur many years after detection of the lesions [44]. BSc has the advantage of detecting abnormalities at multiple sites, but it is unable to quantify the lesions for the purpose of prognosis [45].

\section{Conclusion}

Sickle cell disease is characterized by multifocal osteonecrosis, which leads to many complications as the shoulder and hip joints collapse. Osteonecrosis can be entirely asymptomatic. BSc is a generalized imaging for the entire skeleton with relatively low irradiation. Although MRI is the gold standard for osteonecrosis but the total body MRI is rarely available nowadays and the contrast dye if required is not preferable to use in sickle cell disease because nephropathy is a common complication in these patients. The bone scintigraphy advantages make it safe and necessary for sickle cell disease bone integrity to localize the osteonecrosis, for more detailed study with MRI after locating the lesion. A randomized multicentral research study in using BSc in comparison to MRI as screening and flow up measures in sickle cell disease could proof the superiority of BSc in avoiding the catastrophic bone complications in such patients by early diagnosis and treatment of silent osteonecrosis.

\section{References}

1. Jaffer DE, Amrallah FK, Ali KM, Mohammed NA, Hasan RA, et al. (2009) Adult sickle cell disease patients' knowledge and attitude toward the preventive measures of sickle cell disease crisis. Int J Nurs Midwifery 1: 10-18.

2. Ndefo UA, Maxwell AE, Nguyen H, Chiobi TL (2008) Pharmacological management of sickle cell disease. Pharm Ther 33: 238-243.

3. Athanassiou-Metaxa M, Kirkos J, Koussi A, Hatzipantelis E, Tsatra I, et al. (2002) Avascular necrosis of the femoral head among children and adolescents with sickle cell disease in Greece. Haematologica 87: 771-772.

4. Al-Mousawi F (2004) Complications and failures of hip replacement in sickle cell disease. Bahrain Med Bull 26: 1-8.

5. Mousa SA, Al Momen A, Al Sayegh F, Al Jaouni S, Nasrullah Z, et al. (2010) Management of painful vaso-occlusive crisis of sickle-cell anemia: consensus opinion. Clin Appl Thromb Hemost 16: 365-376.

6. Sharpe CC, Thein SL (2011) Sickle cell nephropathy - a practical approach. Br J Haematol 155: 287-297.

7. Fauci A, Braunwald E, Kasper D, Hauser S, Longo D, et al. (2008) Harrison's principles of internal medicine, $17^{\text {th }}$ Edition. McGraw-Hill Medical.

8. Nath KA, Hebbel RP (2015) Sickle cell disease: renal manifestations and mechanisms. Nat Rev Nephrol 11: 161-171.

9. Andreucci M, Faga T, Pisani A, Sabbatini M, Michael A (2014) Acute kidney injury by radiographic contrast media: pathogenesis and prevention. BioMed Res Int 2014: 21.

10. De Leonardis F, Orzincolo C, Prandini N, Trotta F (2008) The role of conventional radiography and scintigraphy in the third millennium. Best Pract Res Clin Rheumatol 22: 961-979.

11. Love C, Din AS, Tomas MB, Kalapparambath TP, Palestro CJ (2003) Radionuclide bone imaging: An illustrative review. Radio Graphics 23: 341 358.

12. Palestro CJ, Love C (2007) Radionuclide imaging of musculoskeletal infection. Braz Arch Biol Technol 50: 15-27.

13. Dore F, Filippi L, Biasotto M, Chiandussi S, Cavalli F, et al. (2009) Bone scintigraphy and SPECT/CT of bisphosphonate-induced osteonecrosis of the Jaw. J Nucl Med 50: 30-35.

14. Al-Jafar H, Al-Shemmeri E, Al-Shemmeri J, Aytglu L, Afzal U, et al. (2015) Precision of SPECT/CT allows the diagnosis of a hidden Brodie's abscess of the talus in a patient with sickle cell disease. Nucl Med Mol Imaging 49: 153156.

15. Loutfi I, Collier BD, Mohammed AM (2003) Nonosseous abnormalities on bone scans. J Nucl Med Technol 31: 149-153. 
Citation: Al-Jafar H, AlFeeli M, Alhajri FA, Abdullah TA, Al-Shemmeri E. Bone Scintigraphy Scanning Safety and Necessity for Silent and Multifocal Osteonecrosis in Sickle Cell Disease. J Hematol Thromb 2016;2(1): 4.

16. Lin Y, Tsai SC, Wang HY, Lu YY, Lin WY (2010) ${ }^{99 m} T c-M e t h y l e n e$ diphosphonate bone scintigraphy in a young woman with femoral head osteonecrosis after core decompression: A case report and review of the literature. Ann Nucl Med Sci 23: 235-240.

17. Lin KH, Tsao CH, Wu MC, Shih BF (2007) Freiberg's disease involving third metatarsal bone noted by bone scan: A case report. Ann Nucl Med Sci 20 : 47-50.

18. Wang R, Bhandari M, Lachowski RJ (2001) A systematic approach to adult hip pain part 2. Can J Diagnosis: 96-104

19. Almeida A, Roberts I (2005) Bone involvement in sickle cell disease. Br J Haematol 129: 482-490.

20. Gutierrez K (2005) Bone and joint infections in children. Pediatr Clin North Am 52: $779-794$

21. Malizos KN, Karantanas AH, Varitimidis SE, Dailiana ZH, Bargiotas $\mathrm{K}$, et al. (2007) Osteonecrosis of the femoral head: etiology, imaging and treatment. Eur J Radiol 63: 16-28.

22. Griffeth LK (2005) Use of PET/CT scanning in cancer patients: technical and practical considerations. Proc (Bayl Univ Med Cent) 18: 321-330.

23. Sakai T, Sugano N, Nishii T, Haraguchi K, Yoshikawa H, et al. (2001) Bone scintigraphy for osteonecrosis of the knee in patients with non-traumatic osteonecrosis of the femoral head: comparison with magnetic resonance imaging. Ann Rheum Dis 60: 14-20.

24. Agrawal K, Corrigan A, Vijayanathan S, Gnanasegaran G (2014) Radionuclide bone SPECT/CT in orthopaedics. RAD Magazine 40: 13-14

25. (1999) Symptomatic multifocal osteonecrosis: A multicenter study Collaborative Osteonecrosis Group. Clin Orthop Relat Res: 312-326.

26. Mandell GA, Contreras SJ, Conard K, Harcke HT, Maas KW (1998) Bone scintigraphy in the detection of chronic recurrent multifocal osteomyelitis. $J$ Nucl Med 39: 1778-1783.

27. Chan KL, Mok CC (2012) Glucocorticoid-induced avascular bone necrosis: diagnosis and management. Open Orthop J 6: 449-457.

28. Agool A, Glaudemans AW, Boersma HH, Dierckx RA, Vellenga E, et al (2011) Radionuclide imaging of bone marrow disorders. Eur J Nucl Med Mol Imaging 38: 166-178.

29. Kim SK, Miller JH (2002) Natural history and distribution of bone and bone marrow infarction in sickle hemoglobinopathies. J Nucl Med 43: 896-900.

30. Love C, Palestro CJ (2004) Radionuclide Imaging of Infection. J Nucl Med Technol 32: 47-57.

31. Pierce TP, Jauregui JJ, Cherian JJ, Elmallah RK, Mont MA (2015) Imaging evaluation of patients with osteonecrosis of the femoral head. Curr Rev Musculoskelet Med 8: 221-227.
32. Fanning JP, Wesley AJ, Wong AA, Fraser JF (2014) Emerging spectra of silent brain infarction. Stroke 45: 3461-3471.

33. Flouzat-Lachaniete $\mathrm{CH}$, Roussignol X, Poignard A, Mukasa MM, Manicom O (2009) Multifocal joint osteonecrosis in sickle cell disease. Open Orthop J 3: 32-35.

34. Wall BF, Hart D (1997) Revised radiation doses for typical x-ray examinations. Report on a recent review of doses to patients from medical $x$-ray examinations in the UK by NRPB. National Radiological Protection Board. Br J Radiol 70: 437-439.

35. (2006) RADAR medical procedure radiation dose calculator and consent language generator.

36. United Nations Scientific Committee on the Effects of Atomic Radiation (2000) Sources and effects of ionizing radiation, Volume 1: Sources. United Nations Publishing, New York, USA.

37. Braun HJ, Gold GE (2012) Diagnosis of osteoarthritis: imaging. Bone 51: 278 288

38. Bruno MA, Mosher TJ, Gold GE (2009) Arthritis in color: Advanced imaging of osteoarthritis. Elsevier Saunders, Philadelphia, pp. 153-192.

39. Lewington A, MacTier R, Hoefield R, Sutton A, Smith D, et al. (1950) Prevention of contrast induced acute kidney injury (ci-aki) in adult patients on behalf of The Renal Association, British Cardiovascular Intervention Society and the Royal College of Radiologists.

40. Brar SS, Hiremath S, Dangas G, Mehran R, Brar SK, et al. (2009) Sodium bicarbonate for the prevention of contrast induced-acute kidney injury: a systematic review and meta-analysis. Clin J Am Soc Nephrol 4: 1584-1589.

41. Zibis AH, Varitimidis SE, Dailiana ZH, Karantanas AH, Arvanitis DL, et al. (2015) Fast sequences MR imaging at the investigation of painful skeletal sites in patients with hip osteonecrosis. Springerplus 4: 3 .

42. Agrawal S, Aggarwal A, Misra R (2004) Multifocal ostenecrosis in systemic lupus erythematosus consequent to corticosteroids use. J Indian Rheumatol Assoc 12: 156-157.

43. Flouzat-Lachaniete $\mathrm{CH}$, Roussignol X, Poignard A, Mukasa MM, Manicom O (2009) Multifocal joint osteonecrosis in sickle cell disease. Open Orthop J 3 : 32-35.

44. Beyzadeoglu T, Onal A (2012) Treatment of osteonecrosis of the knee. European Instructional Lectures 12: 193-201.

45. Murphey MD, Foreman KL, Klassen-Fischer MK, Fox MG, Chung EM, et al. (2014) From the radiologic pathology archives imaging of osteonecrosis: radiologic-pathologic correlation. Radio Graphics 34: 1003-1028.

46. Health Physics Society Specialist in Radiation Safety (1956) Radiation exposure from medical diagnostic imaging procedures: Health physics society fact sheet.

\section{Acknowledgement}

Our grateful to Kuwait Foundation for the advancement of science ( KFAS ), for funding partially this sickle cell disease Project under code: P116 $13 \mathrm{MM}-01$ 